\title{
GLOBAL AND REGIONAL FACTORS CONTROLLING CHANGES OF COASTLINES IN SOUTHERN IBERIA (SPAIN) DURING THE HOLOCENE
}

\author{
JOSÉ LUIS GOY,* CARI ZAZO, $†$ CRISTINO J. DABRIO, $\ddagger$ JAVIER LARIO, $†$ FRANCISCO BORJA, $\S$ \\ FRANCISCO J. SIERRO* and JOSÉ ABEL FLORES* \\ *Departamento de Geología (Geodinámica), Facultad de Ciencias, Universidad de Salamanca, \\ 37008-Salamanca, Spain \\ $\dagger$ Departamento de Geología, Museo Nacional Ciencias Naturales, C.S.I.C., Jose Gutiérrez Abascal 2, \\ 28006-Madrid, Spain \\ $\ddagger$ Departamento de Estratigrafía (Facultad de Ciencias Geológicas) and Instituto de Geología Económica, \\ C.S.I.C., Universidad Complutense, 28040-Madrid, Spain \\ $\S$ Area de Geografía Física, Facultad de Humanidades, Universidad de Huelva, 21007-Huelva, Spain
}

\begin{abstract}
The interaction between global (glacio-eustatic sea-level rise) and regional factors (oceanographic and tectonic) has controlled the evolution of coastline during the Holocene in Southern Iberia.

At ca. $10,000{ }^{14} \mathrm{C}$ years BP a deceleration of relative sea-level rise took place both in the Atlantic and Mediterranean littorals, with a maximum transgression at $6450{ }^{14} \mathrm{C}$ years BP. In subsiding areas (present tidal flats) estuaries illustrate a clear marine influence recorded both in sediments and the fauna while in uplifting areas prograding spit-bar systems developed. Two phases of major progradation are distinguished in these systems: the first one between 6450 and $3000{ }^{14} \mathrm{C}$ years $\mathrm{BP}$, with a sedimentary gap at ca. $4000{ }^{14} \mathrm{C}$ years $\mathrm{BP}$; and the second one from $2750{ }^{14} \mathrm{C}$ years $\mathrm{BP}$ up to present, with an intervening gap between 1200 and $1050{ }^{14} \mathrm{C}$ years BP. These progradation phases develop during stillstands followed by relative sea-level fall, while the sedimentary gaps represent relative high sea level. In the Mediterranean areas, with a higher uplift rate, marine terraces almost coeval to those gaps occur.

The most pronounced modifications in littoral dynamics occurred at between 3000 and $2750{ }^{14} \mathrm{C}$ years BP represented by changes in the direction of longshore drift and prevailing winds and in the predominance of progradation over aggradation processes.

At ca. $1000{ }^{14} \mathrm{C}$ years BP the estuaries record a greater fluvial than marine influence, and at 500 years ago an extraordinary increase in coastal progradation took place in all littoral zones. The European Medieval Warm period is characterized, at least during its initial phase, by low pressure climate conditions, while during the Little Ice Age anticyclonic conditions gave rise to a strong coastal progradation.
\end{abstract}

\section{INTRODUCTION}

Global factors, such as the general glacio-eustatic sea-level rise that took place from the Last Glacial Maximum until $6450^{14} \mathrm{C}$ years $\mathrm{BP}$, together with regional factors, such as tectonic or oceanographic ones, control the Holocene evolution of the coastline in the Iberian coast (Zazo et al., 1996a). Here, the coasts of the Southern Iberian Peninsula, the main regional factors are: the tectonic framework (boundary between the European and African plates) with numerous active faults (Fig. 1) during the Late Pleistocene and Holocene that affected the coastline that produced areas of either uplifting or subsiding trends (Zazo et al., 1994). Moreover, the area suffers the effects of the interchange of Atlantic and Mediterranean waters through the Gibraltar Strait, the present input of which bears seasonal variations, being greater in summer under anticyclonic conditions.

Detailed mapping, sedimentological analysis, archaeological and historical studies, and radiocarbon datings (Tables 1 and 2) carried out mainly in spit-bar systems, suggested the existence of two major phases of coastal progradation: the older one lasted from $6450-3000{ }^{14} \mathrm{C}$ years BP with a sedimentary gap or period of reduced sedimentation around ca. $4000{ }^{14} \mathrm{C}$ years $\mathrm{BP}$; the younger one extends from $2750{ }^{14} \mathrm{C}$ years $\mathrm{BP}$ to Present, with an intervening gap in sedimentation between 1200 and 1050 ${ }^{14}$ C years BP. Zazo et al. (1994) and Lario et al. (1995) have interpreted that the phases of progradation occur during periods of stillstand to gentle sea-level fall (minor lowstands), and are also related to increased entrance of 'Superficial Atlantic Waters' in the Mediterranean under anticyclonic conditions. 


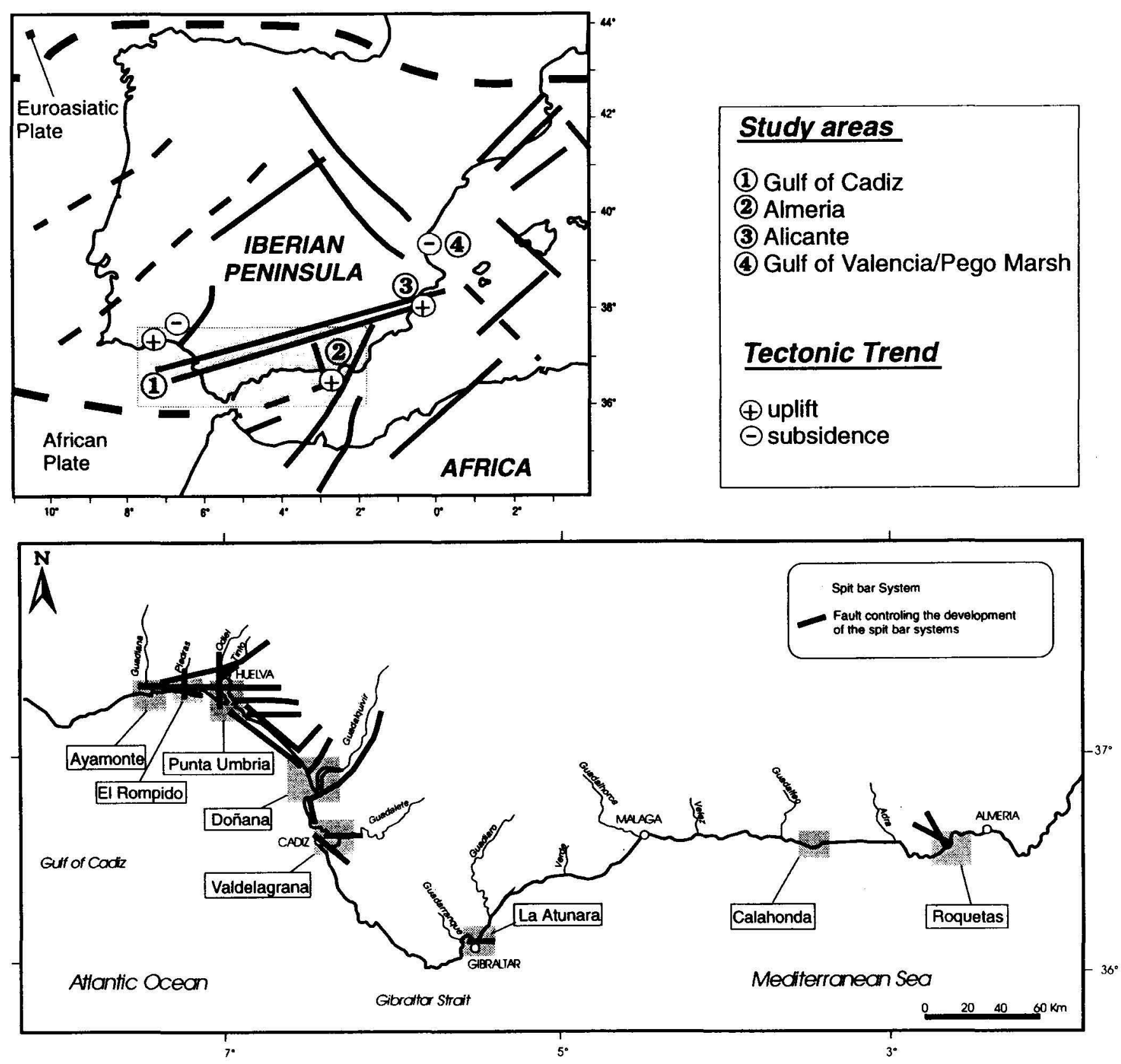

FIG. 1. Location of the study area and main fault systems affecting Late Pleistocene and Holocene coastal deposits.

More ${ }^{14} \mathrm{C}$ analysis and archaeological data, and increased availability of drill cores in the estuaries of Guadalete (Dabrio et al., 1995) and Guadalquivir (Goy et al., 1995) show evidence of rapid modifications to coastlines in Southern Iberia because of changes in littoral dynamics (changes in direction of prevailing winds and littoral drift) both before and after the two phases of coastal progradation (Tables 1 and 2).

The aims of this paper are: (1) to analyze the changes produced in the surveyed coastline and the main factors responsible for these changes during the Holocene, based on the analysis of the exposed morphosedimentary units (spit bars, tidal flats, deltas, alluvial plains) and drill cores from Gulf of Cadiz (Atlantic) and Gulf of Valencia (Viñals, 1991; Viñals and Fumanal, 1995); (2) to place these changes in a chronological sequence based upon radiocarbon dating (using uncorrected radiocarbon ages), archaeological, and historical data; and (3) to compare the changes with the classic climate changes described in Northern Europe.

\section{CHANGES OF COASTLINES CA. $10,000{ }^{14} \mathrm{C}$ YEARS BP}

Figure 2 shows the main changes observed in coastal morphology of Southern Iberian Peninsula taking into account the variable geodynamic behaviour both in tidal range (mesotidal in Atlantic and microtidal in Mediterranean) and the tectonic trend (uplift/subsidence). Data from morphosedimentary units exposed on land or drowned (estuaries, tidal flats, alluvial plains, peat 
TABLE 1. ${ }^{14} \mathrm{C}$ Ages of coastal deposits from south and southeast Spain

\begin{tabular}{|c|c|c|c|c|c|c|}
\hline Sample & Locality & Laboratory & ${ }^{14} \mathrm{C}$ years $\mathrm{BP}$ & Material & Unit & Reference \\
\hline PG-12 & La Atunara & UQM & $2675 \pm 110$ & shell & beach & Lario et al., 1995 \\
\hline PG-13 & La Atunara & UQM & $3200 \pm 110$ & shell & beach & Lario et al., 1995 \\
\hline PG-14 & La Atunara & UQM & $3140 \pm 120$ & shell & beach & Lario et al., 1995 \\
\hline PEGO & Alicante & R-2013 & $6130 \pm 100$ & shell & beach & Viñals and Fumanal, 1995 \\
\hline $\mathrm{CH}-1$ & Calahonda & LGQ-1025 & $1520 \pm 170$ & shell & spit bar & Lario et al., 1995 \\
\hline $\mathrm{CH}-2$ & Calahonda & LGQ-1026 & $2720 \pm 180$ & shell & spit bar & Lario et al., 1995 \\
\hline $\mathrm{CH}-3$ & Calahonda & LGQ-1027 & $800 \pm 190$ & shell & spit bar & Lario et al., 1995 \\
\hline $\mathrm{CH}-4$ & Calahonda & LGQ-1028 & $720 \pm 190$ & shell & spit bar & Lario et al., 1995 \\
\hline $\mathrm{R}-8$ & Roquetas & UQM & $6450 \pm 100$ & shell & spit bar & Goy et al., 1986 \\
\hline R-7 & Roquetas & UQM & $3600 \pm 100$ & shell & spit bar & Goy et al., 1986 \\
\hline $\mathrm{R}-10$ & Roquetas & UQM & $2150 \pm 400$ & shell & spit bar & Goy et al., 1986 \\
\hline $\mathrm{R}-2$ & Roquetas & UQM & $1870 \pm 35$ & shell & spit bar & Goy et al., 1986 \\
\hline F-24 & La Atunara & IRPA-1159 & $1210 \pm 35$ & shell & spit bar & \\
\hline $\mathrm{H}-2$ & El Rompido & R-2179 & $1460 \pm 50$ & shell & spit bar & Zazo et al., 1994 \\
\hline $\mathrm{H}-3$ & El Rompido & R-2180 & $1875 \pm 50$ & shell & spit bar & Zazo et al., 1994 \\
\hline $\mathrm{H}-4$ & El Rompido & R-2207 & $1440 \pm 50$ & shell & spit bar & Zazo et al., 1994 \\
\hline H-5 & El Rompido & R-2203 & $2605 \pm 50$ & shell & spit bar & Zazo et al., 1994 \\
\hline D-2 & Doñana & R-2187 & $1790 \pm 50$ & shell & spit bar & Zazo et al., 1994 \\
\hline D-7 & Doñana & R-2206 & $2185 \pm 50$ & shell & spit bar & Zazo et al., 1994 \\
\hline D-9 & Doñana & R-2185 & $1860 \pm 50$ & shell & spit bar & Zazo et al., 1994 \\
\hline D-11 & Doñana & R-2210 & $2010 \pm 50$ & shell & spit bar & Zazo et al., 1994 \\
\hline D-14 & Doñana & R-2204 & $1490 \pm 50$ & shell & spit bar & Zazo et al., 1994 \\
\hline D-15 & Doñana & UtC-4185 & $2340 \pm 60$ & shell & spit bar & \\
\hline D-16 & Doñana & UtC-4188 & $1650 \pm 50$ & shell & spit bar & \\
\hline D-17 & Doñana & R-2188 & $1850 \pm 50$ & shell & spit bar & Zazo et al., 1994 \\
\hline D-18 & Doñana & UtC-4192 & $1370 \pm 60$ & shell & spit bar & \\
\hline $\mathrm{C}-3$ & Valdelagrana & $\mathrm{R}-2182$ & $2320 \pm 50$ & shell & spit bar & Zazo et al., 1994 \\
\hline C-4 & Valdelagrana & R-2208 & $3145 \pm 50$ & shell & spit bar & Zazo et al., 1994 \\
\hline C-5 & Valdelagrana & R-2181 & $2270 \pm 50$ & shell & spit bar & Zazo et al., 1994 \\
\hline$C-6$ & Valdelagrana & R-2186 & $2120 \pm 50$ & shell & spit bar & Zazo et al., 1994 \\
\hline
\end{tabular}

deposits, spit bars, marine terraces, and aeolian dunes) have been incorporated because they are useful for dating (Tables 1 and 2) and because their variable development allows interpretation of many major changes of coastal processes, climate and sea level.

Letters and symbols, in Fig. 2, indicate some processes of coastal dynamics (changes in littoral drift, or wind directions, fauna, and trends of relative sea level) that have been recorded and dated with a certain degree of confidence in the morphosedimentary units. Approximate present elevations of some morphosedimentary units (datum: Present Mean Sea Level, MSL) are indicated.

Drill cores from the Mediterranean area, particularly in the alluvial plain of Valencia Gulf (Viñals, 1991; Viñals and Fumanal, 1995), and in tidal flats of the Gulf of Cadiz (Dabrio et al., 1995; Goy et al., 1995; Zazo et al., 1996b) indicate that the 'global' glacio-eustatic relative rise of sea level prior to ca. $10,000{ }^{14} \mathrm{C}$ years $\mathrm{BP}$ experienced a deceleration that favoured the start of development of peat layers that occur interbedded in lagoonal deposits (Mediterranean coast) or on intertidal flat sediments (Atlantic coast) (Fig. 3). A series of prograding bodies occurring in the shelf at about 50-60 m water depth are interpreted as stillstand deposits (Hernández-Molina et al., 1994).

\section{EVOLUTION OF THE COASTLINE BETWEEN CA. 10,000 AND $6450{ }^{14} \mathrm{C}$ YEARS BP}

\section{Atlantic Littoral}

Wind patterns recorded in the systems of coastal dunes forming the present Asperillo cliff (northwest of the Guadalquivir estuary, Huelva coast), an area with an uplift trend, show a change in the direction of prevailing winds (Borja and Díaz del Olmo, 1995) between two dune deposits separated by a layer rich in organic matter dated (Tables 1 and 2) as ca. $10,000{ }^{14} \mathrm{C}$ years BP (Zazo et al., 1996a). Wind directions changed from SW to $W$ (palaeocurrents pointing towards the NE and $\mathrm{E}$ respectively).

Cores drilled in tidal flats of the Gulf of Cadiz (Fig. 3) record the rise of sea level as estuarine clay that directly overlay peat layers. Upward increase in sand content and faunal content indicate partial filling of the estuary and development of tidal flats.

Analysis of microfauna (Fig. 4) reveals a noticeable increase of Miliolids and fragments of Echinoderms and a decrease of Haynesina germanica and Elphidium excavatum in sediments deposited between 8000 and 7000 ${ }^{14} \mathrm{C}$ years BP. We think that the change is related to moreopen marine conditions in the estuaries during this time. 
TABLE 1. cont'd

\begin{tabular}{|c|c|c|c|c|c|c|}
\hline Sample & Locality & Laboratory & ${ }^{14} \mathrm{C}$ yearsBP & Material & Unit & Reference \\
\hline PU95-1 & Punta Umbría & GX-20907 & $3315 \pm 70$ & shell & spit bar & \\
\hline PU95-2 & Punta Umbría & GX-20908 & $3555 \pm 75$ & shell & spit bar & \\
\hline PU95-3 & Punta Umbría & GX-20909 & $1900 \pm 70$ & shell & spit bar & \\
\hline IC95-1 & $\begin{array}{l}\text { Ayamonte } \\
\text { (I.Canela) }\end{array}$ & GX-20899 & $835 \pm 65$ & shell & spit bar & \\
\hline IC95-3 & $\begin{array}{l}\text { Ayamonte } \\
\text { (I.Canela) }\end{array}$ & GX-20900 & $3130 \pm 70$ & shell & spit bar & \\
\hline AG-1 & Alicante & SAN-CEDEX & $5190 \pm 300$ & shell & marine terrace & Gozalvez, 1985 \\
\hline AG-2 & Alicante & SAN-CEDEX & $3640 \pm 330$ & shell & marine terrace & Gozalvez, 1985 \\
\hline $\mathrm{AG}-4$ & Alicante & SAN-CEDEX & $5540 \pm 170$ & shell & marine terrace & Gozalvez, 1985 \\
\hline F-17 & $\begin{array}{l}\text { S.Roque-La } \\
\text { Atunara }\end{array}$ & UtC- $4189^{1}$ & $2760 \pm 50$ & shell & marine terrace & \\
\hline PEGO-1 & Alicante & UBAR-77 & $10,120 \pm 460$ & organic mud & marsh & Viñals and Fumanal, 1995 \\
\hline PEGO-3 & Alicante & UBAR-78 & $8300 \pm 90$ & organic mud & $\operatorname{marsh}^{2}$ & Viñals, 1991 \\
\hline PEGO-5 & Alicante & UBAR-43 & $7120 \pm 90$ & organic mud & $\operatorname{marsh}^{2}$ & Viñals, 1991 \\
\hline LP-13 & Guadalquivir & $\mathrm{UtC}-4026^{1}$ & $2490 \pm 60$ & twigs & estuary $^{2}$ & \\
\hline LP-13 & Guadalquivir & $\mathrm{UtC}-4031^{1}$ & $2930 \pm 60$ & shell & estuary $^{2}$ & \\
\hline PSM104/C0 & Guadalete & GX-20913 ${ }^{1}$ & $3505 \pm 55$ & organic muds & estuary $^{2}$ & \\
\hline PSM104/C3 & Guadalete & GX-20914 ${ }^{1}$ & $5885 \pm 60$ & shell & estuary $^{2}$ & \\
\hline PSM104/C5 & Guadalete & $\mathrm{GX}-20925^{1}$ & $6420 \pm 45$ & shell & estuary $^{2}$ & \\
\hline PSM104/C9 & Guadalete & $\mathrm{GX}-20916^{1}$ & $7620 \pm 55$ & shell & estuary $^{2}$ & \\
\hline PSM104/C11 & Guadalete & GX-20917 ${ }^{1}$ & $7840 \pm 45$ & shell & estuary $^{2}$ & \\
\hline PSM104/C15 & Guadalete & GX-20918 & $8040 \pm 55$ & shell & estuary $^{2}$ & \\
\hline PSM104/C20 & Guadalete & GX-20919 & $8915 \pm 100$ & peat & estuary $^{2}$ & Dabrio et al., 1995 \\
\hline PSM104/C21 & Guadalete & GX-20920 & $9495 \pm 340$ & peat & estuary $^{2}$ & Dabrio et al., 1995 \\
\hline A-7 & El Asperillo & LGQ-759 & $10,500 \pm 50$ & peaty sand & dune slack & Zazo et al., 1996a \\
\hline A-7B & El Asperillo & LGQ-897 & $11,240 \pm 220$ & peaty sand & dune slack & Zazo et al., 1996a \\
\hline
\end{tabular}

(1) AMS; (2) core Laboratories: UQM - GEOTOP, Université du Québèc à Montreal, H3C 3P8 Montréal, Canada; R - Dip. Fisica, Centro di Studio per la Geochimica Aplicata, Universitá 'La Sapienza', Roma, Italy; LGQ - Lab. de Géologie du Quaternaire, CNRS, Luminy, 13288 Marseille, France; IRPA Institute Royal du Patrimonie Artistique, 1040 Bruxelles, Belgium; UtC - R.J. Van de Graaf Lab. 35080 TA Utrecht, The Netherlands; GX - Geochron Laboratory, Cambridge, Massachusetts, 02138 USA; SAN CEDEX - Serv. Aplic.Nucleares, Centro de Est. y Experiment. de O.P., Madrid, Sapin. UBAR Dept. Química Analítica, Universidad de Barcelona, CETA - CEDEX, Barcelona, Spain.

\section{Mediterranean Littoral}

A layer of basal peat found in cores drilled in the Pego marsh (Viñals, 1991; Viñals and Fumanal, 1995) provides ages ranging from $10,120 \pm 460$ to $7120 \pm 90{ }^{14} \mathrm{C}$ years BP as it was deposited progressively landwards and peat layers were drowned and covered by retreating-beach deposits. This arrangement suggests coastal onlap and the corresponding relative rise of sea level.

The Holocene maximum (Flandrian transgression) has been dated in Southern Spain at $6450{ }^{14} \mathrm{C}$ years BP. This is when the progradation of spit bars began (Goy et al., 1986; Zazo et al., 1994).

\section{EVOLUTION OF THE COASTLINE BETWEEN CA. 6450 AND $3000{ }^{14} \mathrm{C}$ YEARS BP}

The first spit-bar system began to grow in areas with an uplift trend, particularly on the Mediterranean coast. There, in the most complete case study (Roquetas, Almería), the first phase of progradation includes two spit bars called H1 and H2 (Zazo et al., 1994; Goy et al., 1995; Lario et al., 1995) separated from each other by a sedimentary gap at ca. $4000{ }^{14} \mathrm{C}$ years BP (Fig. 2).

In places where the geomorphological context does not favour the development of spit bars and there is a higher uplift trend, there is deposition of two raised marine terraces approximately at $+1 \mathrm{~m}$ above present mean sea level. These have been dated at $5190 \pm 300$ and $5540 \pm 170$, the most ancient one; and $3640 \pm 330{ }^{14} \mathrm{C}$ years BP, the youngest one, in the Alicante coast (Gozalvez, 1985).

In subsiding areas (Gulf of Valencia) drill cores record marine beach deposits dated as $6130 \pm 100{ }^{14} \mathrm{C}$ years $\mathrm{BP}$, overlaying lagoon deposits (Viñals and Fumanal, 1995). These are placed below present MSL.

In the Atlantic area, filling of open estuaries began at this time and aggradation clearly surpassed coastal progradation (Figs 2 and 3). Palaeontological (Fig. 4) and sedimentological data indicate that the marine influence in all the surveyed estuaries was less.

Regarding the relative changes of sea level, we interpret that spit-bar systems began to grow immediately after the maximum glacio-eustatic rise of sea level (ca. $6450{ }^{14} \mathrm{C}$ years BP). Progradation of spits was favoured by stillstand or gentle lowstand conditions, whereas the gap separating spit bars $\mathrm{H} 1$ and $\mathrm{H} 2$ (ca. $4000{ }^{14} \mathrm{C}$ years $\mathrm{BP}$ ) should indicate a positive oscillation (rise) of sea level with gentle transgression inside the general regressive trend of the first phase of progradation. 
analysis, particularly the mean and standard deviation, in the same cores indicate that the main phase of sedimentation with strong fluvial influence occurred after $2750{ }^{14} \mathrm{C}$ years $\mathrm{BP}$.

An extraordinary increase in progradation is detected in both the Atlantic and Mediterranean littorals ca. 500 years ago and, particularly, after the 17th century as demonstrated by the present location of watch towers built up in that time (some of them are $200 \mathrm{~m}$ inland in Doñana spit bar) and also by other historical data like histroical maps and flood records (Lario et al., 1995).

\section{DISCUSSION AND CONCLUSIONS}

The present arrangement of Holocene morphosedimentary units (emerged or drowned marine terraces, spit bars, peat layers) found in the littoral areas of Southern Iberian Peninsula results from the control of: (a) tectonic factors that imposed the rate, sign, and magnitude of subsidence; (b) the distance to sources of sediment supply for the coastal budget (river mouths), and (c) the variable input of superficial Atlantic Waters into the Mediterranean. This is particularly evident from ca. $6500{ }^{14} \mathrm{C}$ years BP up to Present.

The analysis of the morphosedimentary units allowed recontruction of the sea-level history as follows:

(1) The peat layer accumulation at ca. $10,000{ }^{14} \mathrm{C}$ years $\mathrm{BP}$ suggests a deceleration of the general sea-level rise.

(2) Spit-bar systems began to accumulate immediately after the Holocene highstand (at $6450{ }^{14} \mathrm{C}$ years BP) during stillstands followed by gentle relative sealevel falls.

(3) The gaps of sedimentation/progradation in the spitbar systems record relative high sea level. Nevertheless there is a light diachronism with the ages obtained in the Mediterranean raised marine terraces which also developed during relative high sea-level, moreover in the Atlantic littoral the marine terrace exposed at $+1.5 \mathrm{~m}$ in San Roque (La Atunara) is coeval with the gap that separates the two progradation phases (Fig. 2).

(4) Regarding the climate, the input of sediment in our lattitudes increased during floods (short period, strong rain under drought conditions) with anticyclonic conditions; under these conditions (presently in summer) the input of superficial Atlantic Waters in the Mediterranean increases as well.

The initial phase of the European Medieval Warm Period coincides with an epoch of reduced progradation probably under dominantly low-pressure conditions, while the 'Little Ice Age' corresponds to epochs of anticyclonic conditions, that is warm and with strong rain in short periods that results in a high sediment supply to the coast.

Until now, we have recognized several major changes of climatic parameters, recorded in the area as changes of littoral dynamics:

(1) Between 3000 and $2750{ }^{14} \mathrm{C}$ years BP the direction of prevailing winds both in Atlantic and Mediterranean coasts; littoral drift in the Mediterranean coasts changed; and there was an increase of progradation processes, that prevailed upon aggradation.

(2) At ca. $1000{ }^{14} \mathrm{C}$ years BP the coastal palaeogeography of the Atlantic area changed: as connections of estuaries with open sea were drastically reduced, faunas experienced a sudden impoverishment recorded in drill cores as lower diversity and absence of marine faunas in estuarine deposits.

(3) At ca. 500 years ago there was an extraordinary increase of coastal progradation in all the surveyed littorals. The direction of prevailing winds changed in the Atlantic and became the same as present.

\section{ACKNOWLEDGEMENTS}

Research supported by European Union Project EV5V-CT940445, Spanish DGICYT Projects PB92-0023 and PB92-282, Estación Biológica de Doñana C.S.I.C Project 143/90 and Research Fellowship EV5V-CT94-5243. It is a part of INQUA Shorelines Commission and IGCP Project 367.

\section{REFERENCES}

Borja, F. and Díaz del Olmo, F. (1995). Manto eólico litoral del Abalario (Huelva: Episodios morfogenéticos posteriores al 22.000 BP. Resum. Comunicación. Congreso Paleoambientales cuaternarios de la Península Ibérica, Santiago de Compostela, Octubre 1995. Abstract. Vol. 2.

Dabrio, C.J., Goy, J.L., Lario, J., Zazo, C., González, A. and Borja, F. (1995). The Guadalete estuary during the Holocene times (Bay of Cadiz, Spain). INQUA MBSS Subc, Newsletter, 17, 19-22.

Goy, J.L., Zazo, C., Dabrio, C.J. and Hillaire-Marcel, C.L. (1986). Evolution des systèmes de lagons-îles barrière du Tyrrhénien a l'actualité à Campo de Dalías (Almería, Espagne). Edit. de l'Orstom, Coll. Travaux et Docments, 197, 169-171.

Goy, J.L., Zazo, C., Dabrio, C.J., Lario, J., Borja, F., Sierro, F.J. and Flores, J.A. (1995). Global and Regional factors controlling changes of coastlines in southern Iberia during the Holocene. IGCP Project 367: Late Quaternary coastal records of rapid change; Application to present and future conditions.IInd Annual Meeting (Antofagasta, Chile, Nov, 1995), Abst. vol., pp. 37-38.

Gozalvez, V. (1985). Precisiones sobre los depósitos cuaternarios en la antigua albufera del Saladar de Alicante. In: Servicio de Publicaciones Universidad de Valencia (Ed.). Pleistoceno y Geomorfología litoral. Libro Homenaje a Juan Cuerda, pp. $35-52$.

Hernández-Molina, F.J., Somoza, L., Rey, J. and Pomar, L. (1994). Late Pleistocene-Holocene sediments on the spanish continental shelves: Model for very high resolution sequence stratigraphy. Marine Geology, 120, 129-174.

Hernández-Molina, F.J., Somoza, L., Vázquez, J.T. and Rey, J. (1995). Estructuración de los prismas litorales del Cabo de Gata: respuesta a los cambios climáticos-eustáticos holocenos. Geogaceta, 18, 79-82.

Lario, J., Zazo, C., Dabrio, C.J., Somoza, L., Goy, J.L., Bardaji, T. and Silva, P.G. (1995). Record of recent Holocene sediment input on spit bars and deltas of south Spain. In: Core, B. (ed.), Holocene cyclic pulses and sedimentation. Journal of Coastal Research, Special Issue, 17, 241-245. 
Viñals, M.J. (1991). Evolución geomorfológica de la Marjal de Oliva-Pego (Valencia). Ph.D. Thesis, Universidad de Valencia, 466 pp.

Viñals, M.J. and Fumanal, M.P. (1995). Quaternary development and evolution of sedimentary environments in the Central Spanish Coast. Quaternary International, 29/30, 119128.

Zazo, C., Goy, J.L., Somoza, L., Dabrio, C.J., Belluomini, G., Improta, S., Lario, J., Bardají, Bardají and Silva, P.G. (1994). Holocene sequence of sea level fluctuations in relation to climatic trends in the Atlantic-Mediterranean linkage coast. Journal of Coastal Research, 10, 933-945.

Zazo, C., Goy, J.L., Lario, J. and Silva, P.G. (1996). Littoral zone and rapid climatic changes during the last 20,000 years. The Iberia study case. Zeitschrift fur Geomorphology, 102, 119-134.

Zazo, C., Dabrio, C.J., Goy, J.L., Bardaji, T., Ghaleb, B., Lario, J., Hoyos, M., Hillaire-Marcel, Cl., Sierro, F., Flores, J.A., Silva, P. and Borja, F. (1996b). Cambios en la dinámica litoral y nivel del mar durante el Holoceno en el Sur de Iberia y Canarias. Geogaceta, 20, 1679-1682. 